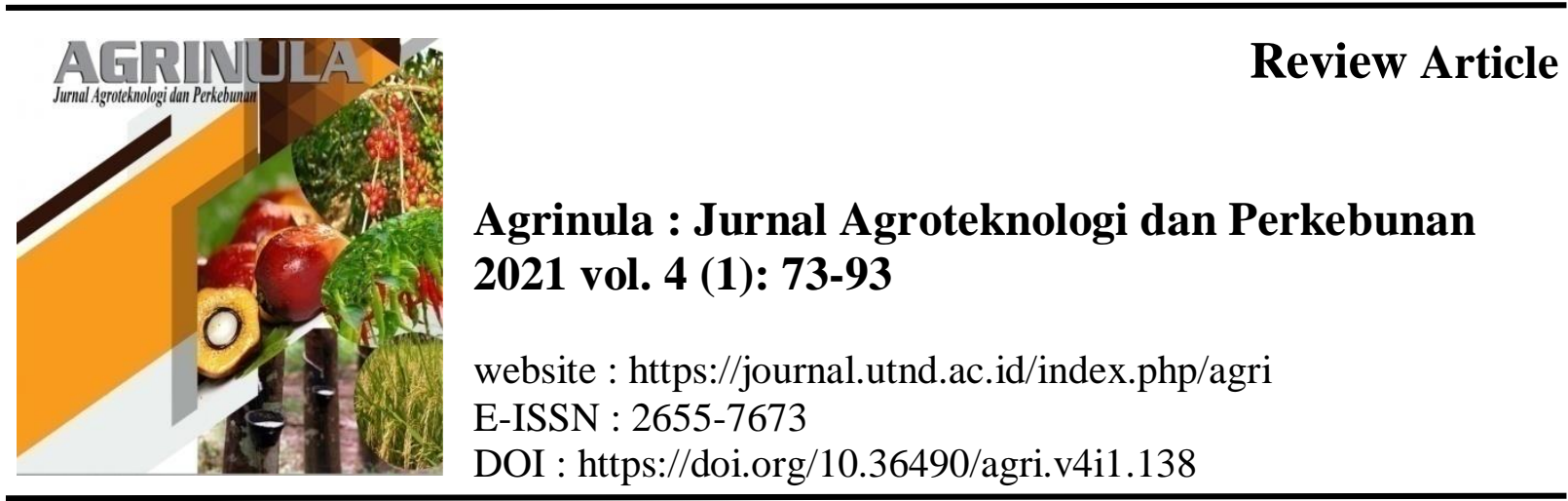

\title{
HYDROPONIC GARLIC PRODUCTION: AN OVERVIEW
}

Muhammad Fraz Ali ${ }^{1 *}$, Ummar Ali ${ }^{1}$, Muhammad Ahsan Jamil ${ }^{1}$, Muhammad Awais ${ }^{2}$, Muhammad Jazib Khan ${ }^{3}$, Muhammad Waqas ${ }^{1} \&$ Muhammad Adnan ${ }^{4}$

${ }^{1}$ Department of Agronomy, Faculty of Agriculture, University of Agriculture, Faisalabad, Pakistan.

${ }^{2}$ Faculty of Agricultural Engineering and Technology, PMAS-Arid Agriculture University, Rawalpindi, Pakistan.

${ }^{3}$ Department of Agronomy, Faculty of Crop and Food Science, PMAS-Arid Agriculture University, Rawalpindi, Pakistan.

${ }^{4}$ Department of Agronomy, College of Agriculture, University of Sargodha, Pakistan.

*Corresponding author: frazali15@gmail.com

\begin{tabular}{|c|c|}
\hline Article Information & ABSTRACT \\
\hline $\begin{array}{l}\text { Submitted: } \\
\text { February 19, } 2021 \\
\text { Revised: } \\
\text { March 12, } 2021 \\
\text { Accepted: } \\
\text { March 13, } 2021 \\
\text { Published: } \\
\text { March 15, } 2021\end{array}$ & $\begin{array}{l}\text { - Introduction: Garlic is an important crop growing all } \\
\text { around the globe for its nutritional and medicinal } \\
\text { purpose. Due to climate change soil production of garlic } \\
\text { is affected and thus lower in yield. For improving the } \\
\text { yield and increasing the quality of vegetables a new } \\
\text { technique was developed is called hydroponic } \\
\text { technology. } \\
\text { Review results: In hydroponic, garlic can be produced } \\
\text { on condition basis by providing proper nutrition and } \\
\text { growth environment including air, light, soilless } \\
\text { mediums, and water requirements. Methods like deep } \\
\text { water culture, nutrient film technique, drip irrigation, } \\
\text { bubble ponics are very common under different soilless } \\
\text { mediums which includes organic, inorganic and } \\
\text { synthetic. A detailed overview on production } \\
\text { technology, nutrition, medium and hydroponic } \\
\text { techniques which are discussed in details are given } \\
\text { below in this review. } \\
\text { Keywords: climate change; garlic; hydroponic production }\end{array}$ \\
\hline
\end{tabular}




\section{INTRODUCTION}

The biggest problem for current days is to meet the demand for providing the food to world's continuously growing population. The agricultural sector is the biggest source for providing the food to world's population (Godfray et al., 2010). As the world population increasing the land area for crop cultivation is decreasing due to construction of buildings, colonies and roads. Farmers use land as growing media for agricultural crops production (Prayoga \& Putra, 2020). As the land area decreasing, a new methodology for the crop production is developed which is called hydroponics. In hydroponics, we provide maximum number of essential nutrients and medium (in which plant anchor its roots to get water and nutrients) for plant growth (Conn et al., 2013). It is basically culturing of plants without the use of soil. Hydroponics culture is the vital potent way to supply food to global community. Most common hydroponics which are used widely are drip system, deep water culture, drain and flood system although, simplest one is called wick system and the latest hydroponics techniques are nutrient film technique and aeroponics system (Bindhya et al., 2020).

Garlic is belongs to Allium family. If we talk about its nutrition quality, it is big source of vitamins (vitamin $\mathrm{B}_{6}$ and vitamin $\mathrm{C}$ ) and other essential vitamins and some minerals such as Selenium, Allicin (an anti-oxidant) and Manganese (Suleria et al., 2015). In diseases cure point of view, its use is very helpful to cure the infections from common cold (Lissiman et al., 2014). In hydroponic garlic is not a common cultured crop because of its some growing difficulties than other crops plants. Hydroponic garlic production system can be improved by modifying its self-made lighting system, substrate and change mind set of growers toward on it instead of conventional system. It also need additional nutrients for completing its growth period. Cultivation of garlic in hydroponics might be a practical and attractive approach to get maximum yield through maintaining the maximum plant density, we obtain maximum yield in less unit area regarding in field.

In Pakistan garlic is produced in all areas, for the consumption of people. For flavouring the variety of food dishes, it plays a vital role globally. Garlic is a frost resistant crop requires cool period for germination of cloves. It requires day light of approximately. 10 hours to enhance the bulb (weight and diameter), cloves number and for reduction in secondary leaves. (Halleck, 2018). Vegetables yield in hydroponic culture is relatively higher than the conventional system. Keeping in view the above literature about garlic importance and production problems, there is a need to design the hydroponics culture for betterment of garlic growth and yield.

\section{REVIEW RESULTS}

\section{Garlic Nutritional Benefits}

Garlic is one of the very popular vegetables and used for its culinary and medicinal attributed in Pakistan. It is an excellent source of vitamin $\mathrm{B}_{6}$ as well as other vitamins and minerals including Manganese, Selenium, Vitamin C and Allin (Suleria et al., 2015). The contents and benefits of nutritional on garlic can be seen in Table 1 and 
Figure 1. Talking about garlic in particular yes it is possible to improve taste and odour by using optimal hydroponics solution. Through the designed protocol in the hydroponics greenhouses, not only push more nutrients into the plants and also produce higher garlic yield, consequently raising the strength of other beneficial compounds such as sugar, organic acids and vitamins (Paek et al., 2005). Researchers revealed that the greater part of its medical advantages are brought about by sulfur elements when a garlic clove is chopped, squashed or bitten. Possibly the most eminent of those is known as allicin. Regardless, allicin is an uncertain worsen that is simply rapidly present in new garlic after it's been cut or crushed (Borlinghaus et al., 2014). Distinctive smell of garlic that may accept a section in garlic's clinical favorable circumstances consolidate diallyl disulfide and s-allyl cysteine (Zarezadeh et al., 2017). The sulfur element from garlic enter the body from the stomach related tract and travel everywhere on over the body, where it applies its intense organic impacts. A well grown hydroponics garlic does have a finer taste, odour and nutritional benefit compared to those by other methods.

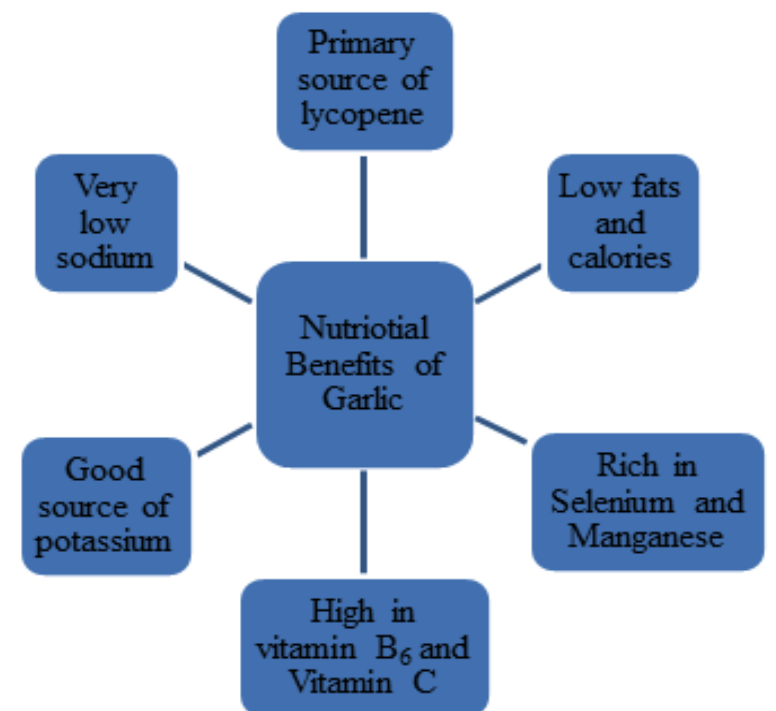

Figure 1. Nutritional benefits of garlic.

Table 1. Garlic nutritional contents

\begin{tabular}{lc}
\hline \multicolumn{1}{c}{ Nutritional value of garlic } & per $100 \mathrm{~g}$ \\
\hline Calories & $321 \mathrm{Kcal}$ \\
Protein & $12.5 \mathrm{~g}$ \\
Fat & $28.57 \mathrm{~g}$ \\
Carbohydrates & $1.79 \mathrm{~g}$ \\
Fiber & $0.1 \mathrm{~g}$ \\
Natural sugars & $1.79 \mathrm{~g}$ \\
Calcium & 0 \\
Fe & $0.05 \mathrm{mg}(0.03 \%$ daily value $)$ \\
$\mathrm{Mg}$ & $1(\mathrm{mg})$ \\
$\mathrm{K}$ & $11(\mathrm{mg})$ \\
Vitamin C & $0.9 \mathrm{mg}(0.02 \%$ daily value $)$ \\
\hline
\end{tabular}

Source: Casado et al., (2004). 


\section{Garlic Production}

Garlic production and area under its production has been increases day by day in Pakistan. According to the estimate of 2017-18, area under garlic and production were 3363 hectares with 27442 tonnes respectively and yield was 9 tonnes per hectare (Government of Punjab, 2019). Garlic produced in many areas of world and is a mainstream product in cooking because of its solid smell and delightful taste. In old occasions, the fundamental utilization of garlic was for its wellbeing and therapeutic properties (Rivlin, 2001). Its utilization was all around reported by many significant developments, including the Egyptians, Babylonians, Greeks, Romans and Chinese (Morihara et al., 2007).

Garlic does not produce via fertile seeds, cloves are used for propagation. In hydroponic culture rockwool blocks or plugs are used to grow cloves (Müller et al., 2000). In hydroponic garlic production nutrients generally supplied by the irrigation system. It should ensure that they have appropriate limit tanks to hold and pass the solution of nutrients (Tank et al., 2017). It is the basic need to examine the best strategy of equal supply of the water and solution of fertilizer to every plant.

Pollination is necessary to produce garlic and it can be accomplished by electric vibrators, bumblebees or air blasts (Saleem, 2018). Garlic is limited to fungal diseases which is white rot. Prevention is the best medicine when it comes to garlic white rot and, as such, it's vital to make sure that all equipment used is properly disinfected (Singh \& Sharma, 2018). Disease control is achieved through crop monitoring and cultural, chemical, physical and biological control strategies. Growers need to utilize all of these methods to ensure a productive operation. Garlic doesn't have insect problems, basically it is an insect repellent crop. Attack of thrips was observed in hydroponic cultivation of garlic which can be controllable (Folorunso et al., 2021). Pest control is necessary to prevent damage to the seedlings and producing plants. Growers must be familiar with potential insect and mite problems and appropriate management practices. Biological control methods are widely practiced by commercial growers, especially if they are using bumblebees for pollination.

Vegetable crops must be harvested at the appropriate stage of growth or maturity in order to maximize their shelf life. As well, greenhouse vegetables need to be cooled after harvest to remove field heat and extend their shelf life. There is a growing concern among consumers about the safety of their food. The grower should follow the good agricultural practices in their operation.

\section{Nutrients and Substrate for Hydroponic Garlic Production}

The nutrients solution is the basic tool for the success or failure of a hydroponic system. Garlic does well with a $\mathrm{pH}$ of at least 6.0-6.5. Most fertilizers which are available in market don't contain all 13 nutrients. Naznin et al., (2009) developed the mixture for the production of garlic under hydroponic system which was given below in Tables 2-4. 
Table 2. Nutrient mixture for the production of garlic under hydroponic system

\begin{tabular}{|c|c|}
\hline Nutrients & Concentration $\left(\mathrm{mg} \mathrm{l}^{-1}\right)$ \\
\hline $\mathrm{NH}_{4}-\mathrm{N}$ & 2.5 \\
\hline $\mathrm{NO}_{3}-\mathrm{N}$ & 11.5 \\
\hline $\mathrm{P}_{2} \mathrm{O}_{5}$ & 5.2 \\
\hline $\mathrm{K}_{2} \mathrm{O}$ & 7.1 \\
\hline $\mathrm{MgO}$ & 4 \\
\hline $\mathrm{MnO}$ & 0.23 \\
\hline $\mathrm{B}_{2} \mathrm{O}_{3}$ & 0.4 \\
\hline $\mathrm{CaO}$ & 8.1 \\
\hline $\mathrm{Fe}$ & 2.8 \\
\hline $\mathrm{Cu}$ & 0.06 \\
\hline $\mathrm{Zn}$ & 0.14 \\
\hline Mo & 0.03 \\
\hline
\end{tabular}

Table 3. General nutrient recipe for the growth of crops grown under hydroponic system

\begin{tabular}{lcc}
\hline \multirow{2}{*}{ Nutrients } & \multicolumn{2}{c}{ ppm or mg per litre } \\
\cline { 2 - 3 } & 210 & Reproductive growth \\
\hline Nitrogen $(\mathrm{N})$ & 50 & 180 \\
Phosphorus $(\mathrm{P})$ & 235 & 40 \\
Potassium $(\mathrm{K})$ & 200 & 300 \\
Calcium $(\mathrm{Ca})$ & 50 & 170 \\
Magnesium $(\mathrm{Mg})$ & 65 & 50 \\
Sulfur (S) & 5 & 60 \\
Iron (Fe) & 0.5 & 5 \\
Manganese $(\mathrm{Mn})$ & 0.05 & 0.5 \\
Zinc (Zn) & 0.5 & 0.05 \\
Boron (B) & 0.02 & 0.5 \\
Copper $(\mathrm{Cu})$ & 0.01 & 0.02 \\
Molybdenum $(\mathrm{Mo})$ & & 0.01 \\
\hline
\end{tabular}

Table 4. Crop nutrition timetable with respect to different crop growth stages

\begin{tabular}{|c|c|c|c|c|c|c|}
\hline $\begin{array}{l}\text { Crop stages } \\
\text { (days after } \\
\text { nursery } \\
\text { transplanting) }\end{array}$ & $\begin{array}{l}\text { Nutrition } \\
\text { solution } \\
\text { *E.C. } \\
\left(\mathrm{dSm}^{-1}\right)\end{array}$ & $\frac{\pi}{2}$ & $\begin{array}{l}\text { Interval } \\
\text { (after } \\
\text { every) }\end{array}$ & $\begin{array}{c}\text { No. } \\
\text { irrigation/day }\end{array}$ & 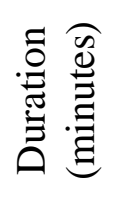 & $\begin{array}{l}\text { Nutrition/plant } \\
\text { (liter) }\end{array}$ \\
\hline 01-14 & 1.5 & \multirow{7}{*}{$5-6$} & $60 \mathrm{~min}$ & 12 & \multirow{7}{*}{2.5} & 1.0 \\
\hline $15-30$ & 1.7 & & & & & 1.5 \\
\hline $31-45$ & 1.8 & & $50 \mathrm{~min}$ & 14 & & \\
\hline $46-60$ & 2.0 & & & & & 2.0 \\
\hline $61-75$ & 2.2 & & $40 \mathrm{~min}$ & 18 & & \\
\hline $76-90$ & 2.4 & & $35 \mathrm{~min}$ & 21 & & 2.5 \\
\hline 90-onward & 2.5 & & $30 \mathrm{~min}$ & 24 & & 2.5 \\
\hline
\end{tabular}

In principle, the soilless medium is a substrate that is part of an artificial system of cultivation in which plants are grown without soil (Figure 2). The medium provides 
plants with physical support, regulates the water flow, serves as reservoir of nutrients and permits gas exchange to and from the roots. A garlic bulb can't develop properly unless it has some sort of material to sustain its bulk. The substrate also helps keep the garlic plant's root system from drying out while also maintaining enough aeration to keep the roots from rotting. Pardossi et al., (2011) reported that the ideal soilless medium should have some physical and chemical properties as follows:

- Uniform texture of the substrate that drains well but retains nutrients and water for the root system.

- Low bulk density to facilitate installation and transportation (between 190 and $700 \mathrm{~kg} \mathrm{~m}^{-3}$ ).

- High porosity of substrate (between $50 \%$ and $85 \%$ ).

- Particle-size distribution to maintain good balance between air and water retention (between 0.25-0.5 mm).

- A pH between 5.0 and 6.5, which can also be adjusted easily.

- Low content of soluble salts.

- Chemical inertia which means that the substrate does not affect the nutrient solution by releasing inorganic ions or immobilizing nutrients.

- Ability to maintain original characteristics so that it can be used for many successive cultivation cycles.

- Absence of pathogens and pests (but not necessarily sterile), and free of any compounds toxic to plants.

- Ability to be produced in uniform batches (to allow the use of consistent fertilization programmes).

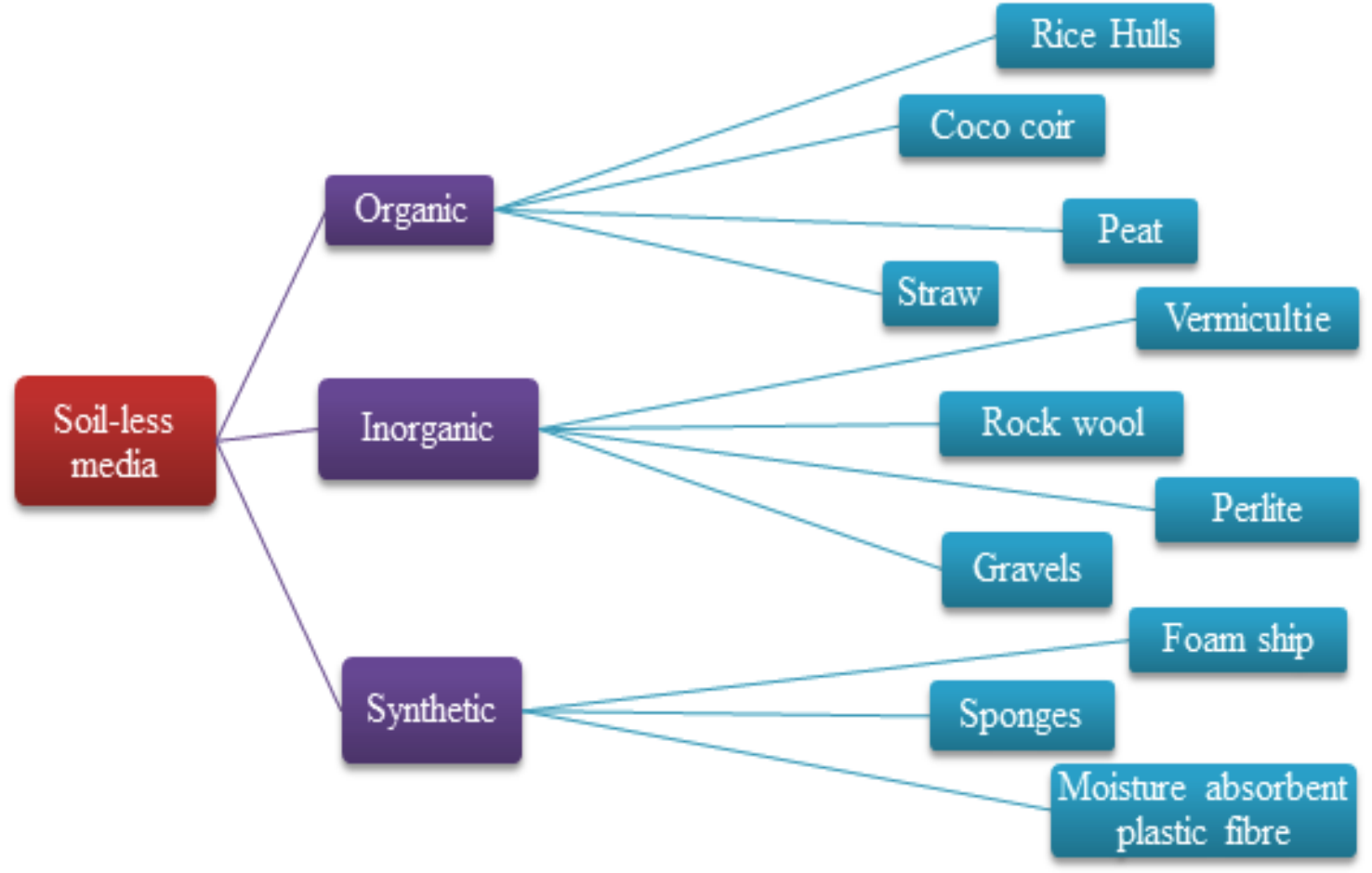

Figure 2. Varieties of Soil-less media used in hydroponics system. 
There are a variety of hydroponic mediums used in soil-less setups that are a good choice for growing garlic (Figure 3).

\section{Coconut Coir}

Coconut coir is a great hydroponic substrate for water retention, but it is best used in conjunction with another airier substrate, such as perlite (Vinci \& Rapa, 2019). Unlike some hydroponic substrates, which are nutrient-neutral, coconut coir is high in nutrients for growing plants to sustain themselves. Coir is an organic medium that offers excellent water and oxygen retention and provides for quality root structure and plant yields. The benefits of coir are as follows; homogeneous structure with excellent water distribution, supplied as a compressed volume which expands $4 \mathrm{x}$ its size when wet, Ideal air/water balance, rapid dense root growth and improved yields, easy to set up and use, stable $\mathrm{pH}$ and $\mathrm{EC}$ values.

\section{Rockwool}

Rock wool is basically fiberglass with some basic changes in composition. Rockwool is formed by superheating rocks and chalk together, then drawing them out into collections of tiny fibres that create a porous, lightweight material to grow plants in. While Rockwool has been a popular form of hydroponic substrate for many years, it is not very environmentally friendly and can be very irritating to the eyes, skin, and respiratory system. There are various grades of horticultural rockwool. The highest quality is made from basaltic rock, which leads to a highly non-reactive rockwool. Nonreactive in the sense that the metals in the rockwool do not react with the minerals in the nutrient solution and produce undesirable results.

\section{Advantages of Rockwool}

- It has a large water retention capacity, and also holds sufficient air. It holds a lot of water which gives advantage against power or equipment failures.

- It holds $18-25 \%$ air which gives the root system ample oxygen so long as the media is not completely submersed.

- It is available in multiple sizes and shapes for various hydroponic applications. Everything from 1 inch cubes to huge slabs.

- Rockwool is also durable, it doesn't readily fall apart or break down.

\section{Disadvantages of Rockwool}

- It is durable but on the other edge makes environmental nuisance. Thrown away it does not biodegrade - it's a rock.

- Rockwool is also a health hazard. Rockwool, like asbestos is made from rocks and minerals the fibers and dust thereof have proven to be extremely hazardous.

- Rockwool has a high $\mathrm{pH}$ and nutrient solutions must be adjusted to accommodate for that factor. It is also susceptible to $\mathrm{pH}$ shifts which creates the need to continuously monitor the $\mathrm{pH}$ levels of system. 
- Rockwool has a high water retention capacity it has a restricted root environment and a low buffering capacity for water and nutrients. The water flow to plant roots may be hindered, even when the water content is apparently high.

\section{Perlite}

Perlite is formed from a volcanic mineral that is superheated until it expands to over twenty times its original size, resulting in a lightweight "popcorn" material that makes heavy soils more friable. Used by itself, it is also an effective hydroponic substrate in most hydroponic systems other than aquaponics which involve fish and other water-breathing animals. The main advantages of using perlite includes, it usually reusable, deals with anaerobic conditions, inexpensive, sterile and $\mathrm{pH}$ neutral. Its disadvantages are; it is not renewable resource, can block aggressive root systems and vulnerable to solids loading.

\section{Vermiculite}

Like perlite, vermiculite is a natural mineral that is superheated until it expands, and it has many of the same properties as perlite. The largest difference between vermiculite and perlite is that vermiculite is better at water retention than perlite, which tends to dry out.Two features of vermiculite lead to its unique shape and numerous uses.

- A layered, crystalline structure within the mineral provides the hinged plates that make the material expand or unfold in a linear manner, like an accordion, when heated.

- Trapped water flashes into steam when heated, forcing the layers open.

\section{Advantages of Vermiculite}

- It has $\mathrm{pH}$ close to neutral and high water retention.

- Takes a long time for particles to dry out so the root zone stays wet longer.

- Holds onto nutrients well (high cation exchange capacity) because of platy structure.

- It can be used alone or mixed with other media to create potting mixes.

- Its sterile nature makes it highly suitable for starting seeds. There is little risk of root rot or damping-off.

- Great for seed germination or plant propagation as the particles let plants be pulled from the perlite without damage to the root systems when it's time for transplanting.

- Reusable year after year since it doesn't decompose.

\section{Disadvantages of Vermiculite}

- Holds onto too much moisture for some plants.

- Carbonate compounds foster alkaline reactions, raising $\mathrm{pH}$ in the root zone.

- Nonrenewable resource. Although more readily available than peat moss, it isn't considered renewable like coconut coir.

- Difficult to find in the retail home gardening marketplace. 
Any of these substrates can be used to grow hydroponic garlic. The main thing to remember is that we need at least some kind of substrate to sustain garlic in order to get it to reliably develop a bulb in a hydroponic setup.

Rockwool is one of the most popular substrates used to grow hydroponic garlic, mostly due to its ability to retain water without keeping the garlic soggy. Garlic prefers pretty dry growing conditions, so finding the right balance between water retention and aeration is key.

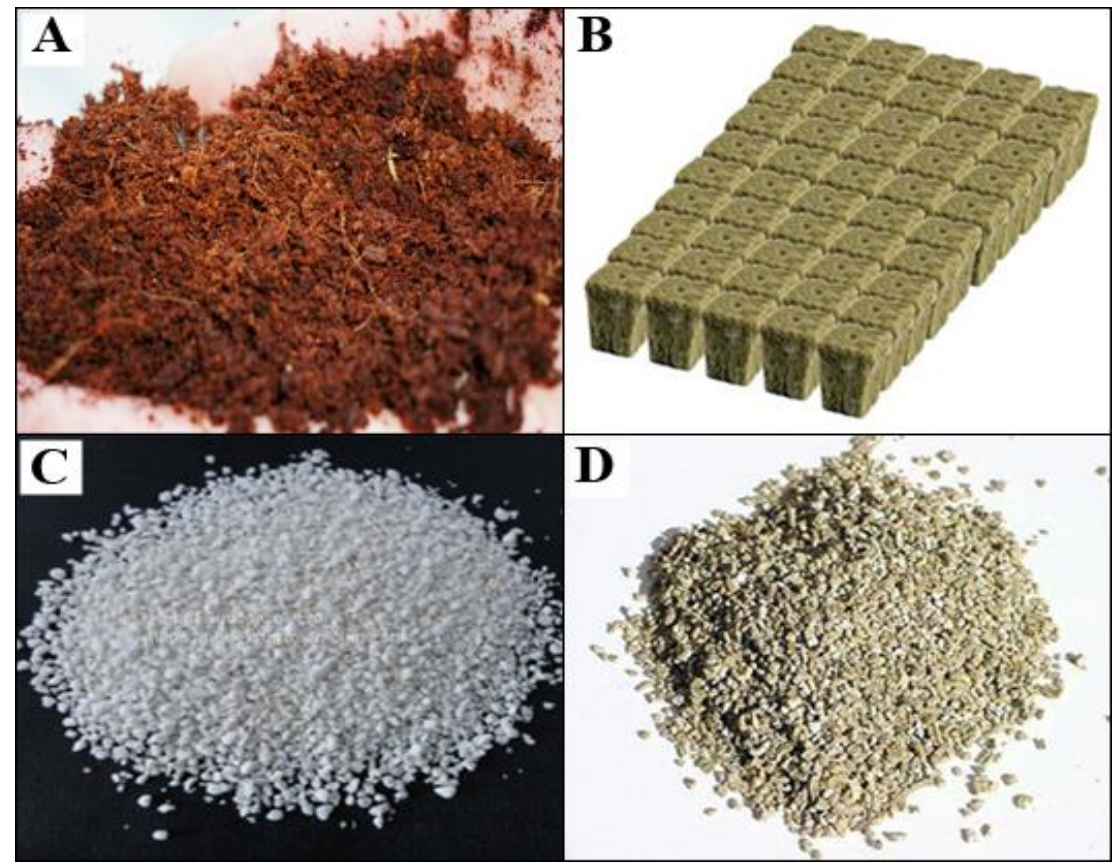

Figure 3. Pictorial presentation of different soilless mediums used in hydroponic garlic production. $\mathrm{A}=$ Coconut coir; $\mathrm{B}=$ Rockwool; $\mathrm{C}=$ Perlite; $\mathrm{D}=$ Vermiculite.

\section{Selection of Hydroponic Systems for Garlic Production}

Fundamentally there are six types of hydroponic systems which are currently used in hydroponic garlic system there details are given in Figure 4. After these basic design then there are hundreds of variations on these basic types of systems used, but all hydroponic methods are a variation (or combination) come from these six.

\section{Wick Irrigation Systems}

Wick system is the simplest type of hydroponic system which is used for garlic production (Figure 5). This is a passive system and does not have any moving parts. Nutrient solution is to be put into the growing medium from the reservoir with a wick. Growing mediums for this system varies from crop to crop but commonly we used perlite, vermiculite, Pro-Mix and Coco-coir. The basic principle for working is that "Wick System uses two or more wicks to deliver water from the reservoir to the roots via capillary action". 


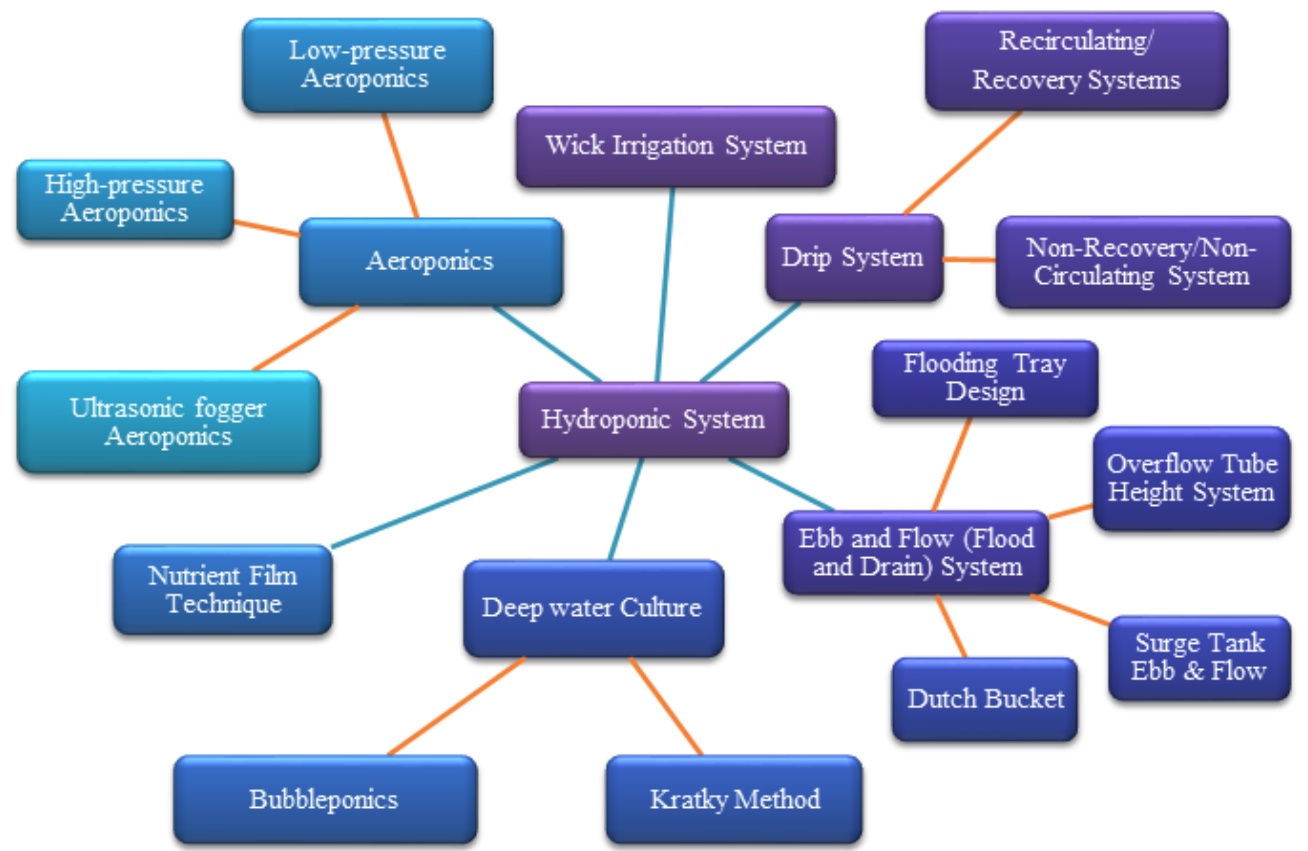

Figure 4. Types of hydroponic systems

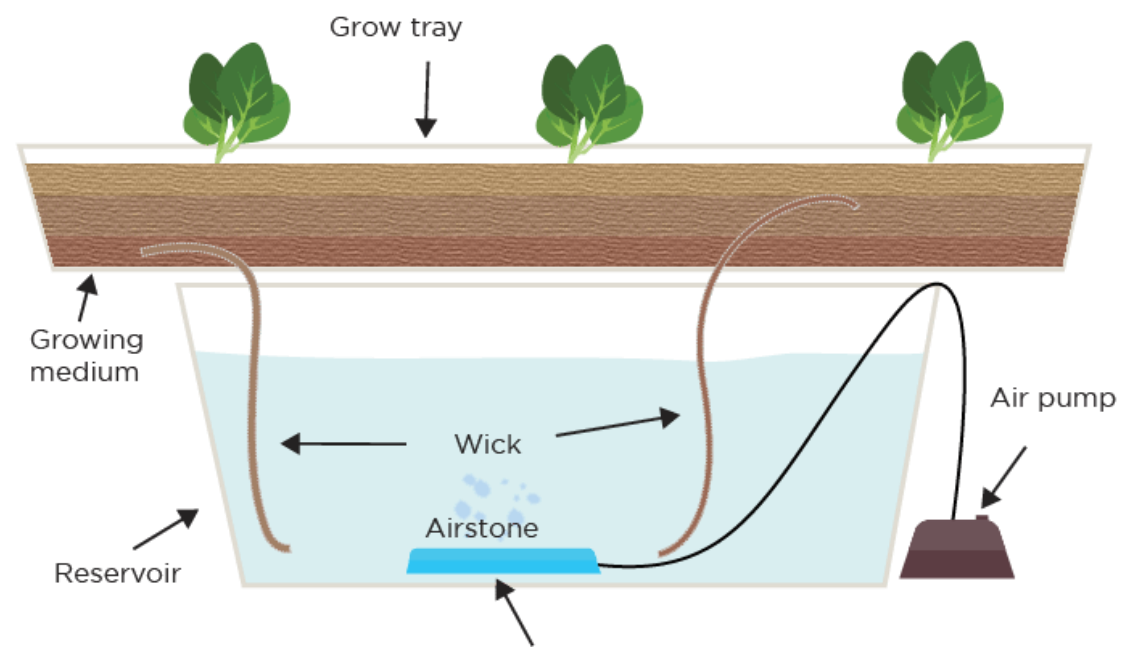

Figure 5. Diagram for a simplest wick hydroponic system

\section{Requirement for Installing a Wick System}

It is very easy to design a wick system for hydroponic production. Only few materials are required to set up a wick system. It also doesn't take up much space. Basically we need a wick, growing tray, reservoir and an air pump for the proper setup of wick system.

\section{Advantages of Wick System}

- It is the modest form of hydroponics; very accessible and easy to control for beginners.

- It is cheap and easy to setup.

- The maintenance of wick system is very low as there are no heavy equipment. 
- Uses minimal energy inputs.

- Ideal for smaller plants like herbs and lettuce.

- Space utilization is less. This system doesn't use much space as it only require a container space.

- This method is ideal for small plant so can decorate your house window sills or balconies.

\section{Disadvantages of Wick System}

- It is not suitable for larger, water-hungry plants and vegetables.

- Inefficient at delivering nutrients at larger scale.

- Prone to toxic nutrient build up in growing media.

- There is salt build up in growing media which means it needs to be washed regularly which can be tiresome.

- There is also the chance of growing medium to not properly absorb the water which can cause the plant to die off.

\section{Drip Irrigation Hydroponic Systems}

Drip systems are probably the most widely used type of hydroponic system in the world (Figure 6). Operation is simple, a timer controls a submerged pump. The timer turns the pump on and nutrient solution is dripped onto the base of each plant by a small drip line. In a Recovery Drip System the excess nutrient solution that runs off is collected back in the reservoir for re-use. The Non-Recovery System does not collect the run off.

\section{Principle}

The working principles behind the hydroponic drip irrigation system are "The drip system consists of a grow tray holding several grow cups and is separate from the solution reservoir. A submersible water pump pumps nutrient-rich solution from the reservoir through a drip irrigation network to the grow cups. Each drip line ends at the base of each plant thereby emitting the solution next to plant reducing moisture wastage".



Figure 6. Diagram for a drip irrigation hydroponic systems. 


\section{Types of Drip Irrigation Hydroponic Systems Recirculating/Recovery Systems}

A recovery system uses nutrient solution more efficiently, as excess solution is reused, this also allows for the use of a more inexpensive timer because a recovery system doesn't require precise control of the watering cycles. A recovery system can have large shifts in the $\mathrm{pH}$ and nutrient strength levels that require periodic checking and adjusting. This type of system has following characteristics:

- When the water is added to the hydroponic medium, all of it is not absorbed by the roots of the plant. In recovery systems, the excess water left behind in the medium is allowed to flow back to the reservoir.

- This kind of a system is very popular for smaller, home-based drip hydroponic setups. While it is more efficient in its use of water and nutrients, the system also has some drawbacks.

- When the wastewater is allowed to flow back to the reservoir, it affects the $\mathrm{pH}$ level of the reservoir water. This means you have to perform periodic maintenance on recovery systems.

- The reservoir water will have to check to ensure that the optimum $\mathrm{pH}$ and nutrient levels are maintained. This is easier and more cost-effective in smaller drip systems.

\section{Non-Recovery/Non-Circulating System}

The non-recovery system requires less maintenance due to the fact that the excess nutrient solution isn't recycled back into the reservoir, so the nutrient strength and $\mathrm{pH}$ of the reservoir will not vary. This means that you can fill the reservoir with $\mathrm{pH}$ adjusted nutrient solution and then forget it until you need to mix more.

The non-recovery system needs to have a more precise timer so that watering cycles can be adjusted to insure that the plants get enough nutrient solution and the runoff is kept to a minimum. This system has following characteristics:

- In this system, any excess water is allowed to run off as waste. In usual circumstances, it is not very desirable to waste the water and nutrients like this. But since drip systems are highly conservative, the scale of wastage is relatively less.

- This kind of system is very popular in larger commercial drip hydroponic setups. Commercial growers have the ability to use sophisticated timers to have maximum control over the water flow. This can keep run-off to a minimum.

- There is another factor that makes such a system highly desirable for commercial growers. It requires lesser maintenance to the reservoir water.

- You don't have to worry about the recycled water altering the $\mathrm{pH}$ and nutrient levels in the reservoir water.

\section{Requirements for Installing a Drip Hydroponic System}

The drip hydroponic system is very flexible. It can scale well according to the size and complexity of a growing operation. For a basic drip system, following items are essential items: 
- Drip Emitters: It depends upon on the number of plants we plan to grow, one emitter for each plant.

- Thin Tubing

- PVC Tubing

- Water Pump: a regular submersible pump is more than adequate for the task. Capacities of between 120-300 gallons per minute should suffice for smaller setups.

- A Tray

- A Large Bucket/Bin

- Small pots for your plant

- A Garden timer for the pump

- Aquarium grade silicone sealant

- A Hydroponic growing medium

- A power drill, and hacksaw or PVC cutter

\section{Advantages}

In hydroponics, a drip system has the following advantages:

- Provides more control over water and nutrient supply

- Flexible system that can be scaled for growth

- Requires low maintenance compared to other methods

- Affordable and cheap installation

- Less chance of system failure

\section{Disadvantages}

- It also has the disadvantages as follows, especially from a non-commercial perspective:

- Might be too complex for a very small grow operation

- If using water recycle system, maintenance is high (for reservoir water)

- If using non-recovery system, there is chance of waste

\section{Floating Deep Water Cultures}

The water culture system is the simplest of all active hydroponic systems (Figure 7). The platform that holds the plants is usually made of Styrofoam and floats directly on the nutrient solution. An air pump supplies air to the air stone that bubbles the nutrient solution and supplies oxygen to the roots of the plants.

Water culture is the system of choice for growing leaf lettuce, which are fast growing water loving plants, making them an ideal choice for this type of hydroponic system. Very few plants other than lettuce will do well in this type of system.

\section{Principle}

"Plants absorb sufficient oxygen while also able to take up the nutrients and water around it all days. This helps them to get a fast growth, and in many cases better than grown in the soil-counterparts." 


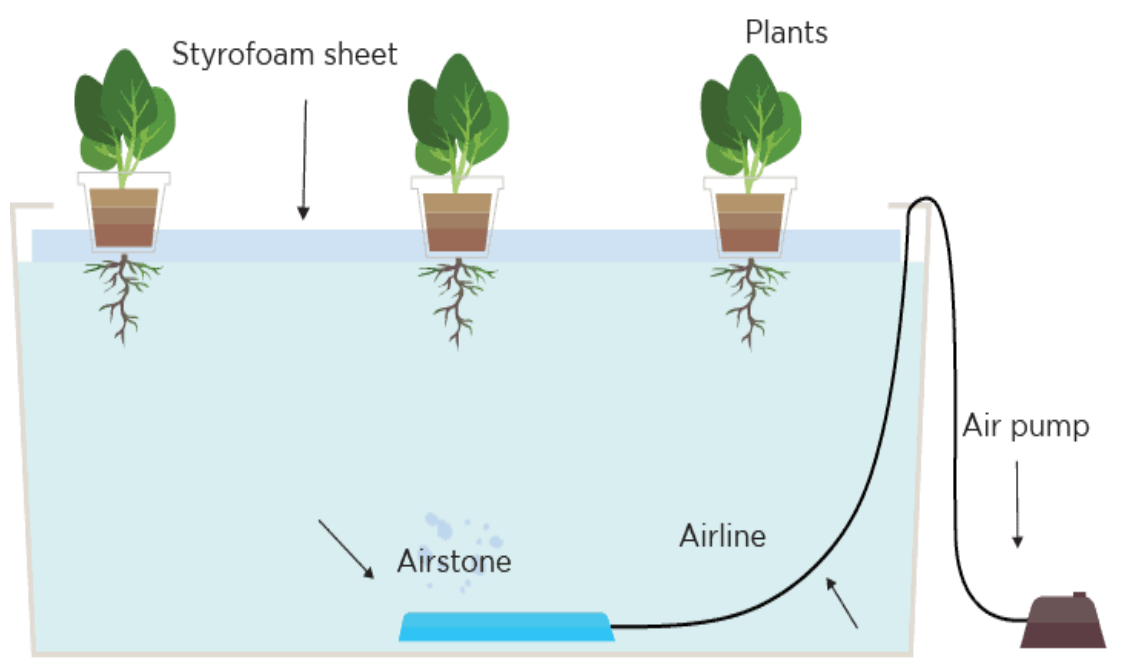

Figure 7. Diagram for a floating deep water culture hydroponic system.

\section{Types of Deep Water Culture}

Above and beyond the traditional deep water culture, there are some varieties of this system type.

\section{Bubbleponics}

Bubbleponics is just like the deep water culture (DWC) with the same set-up, and equipment (air pump, airstone) can be presented in Figure 8. It only upgrades by adding a water pump inside of the reservoir to move the nutrient solutions to top of net cups that hold plants and then fall back to the reservoir. That means bubbleponics is a top feeding DWC and a recirculating system.

- Bubbleponics proves to be useful at the beginning phase of plants when the roots are still short, and cannot fully reach the water below.

- Providing with nutrients and water at this stage helps the roots grow faster, and when they can sink deep into the reservoir's nutrient solution.

- Bubbleponics is really worth doing as it does speed up the seedling and germination phase of crops

\section{Bubbleponics}

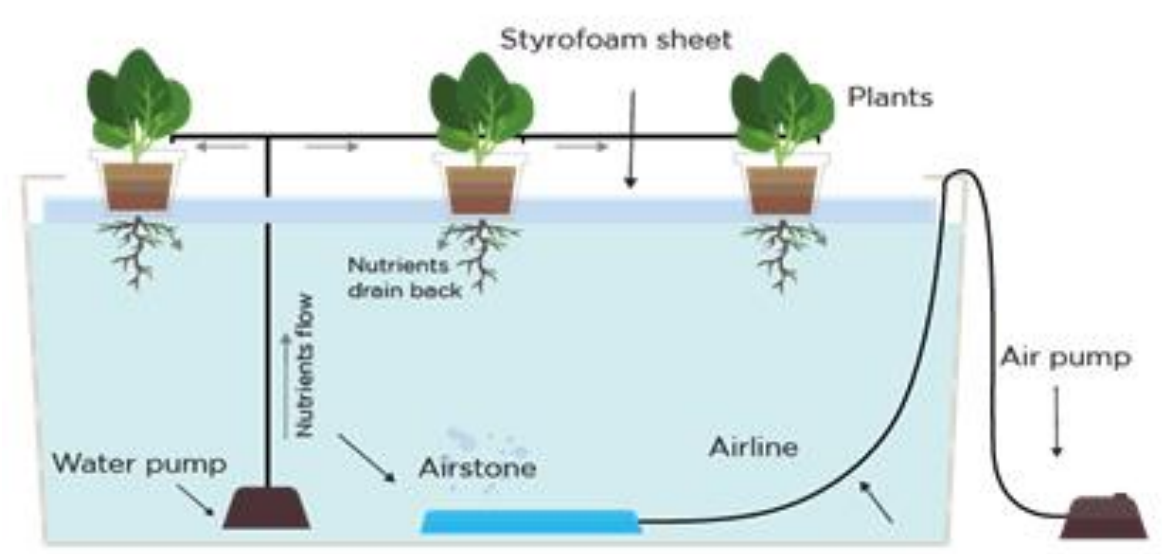

Figure 8. Diagram for a floating deep water culture hydroponic system. 


\section{The Kratky Method}

Kratky method is the deep water culture, but it comes without a pump (Figure 9). This is a passive system with no electricity used. There is an air gap between the roots and the surface of the nutrient solutions. That means parts of the roots are submerged in the waters while the other parts are exposed to the air

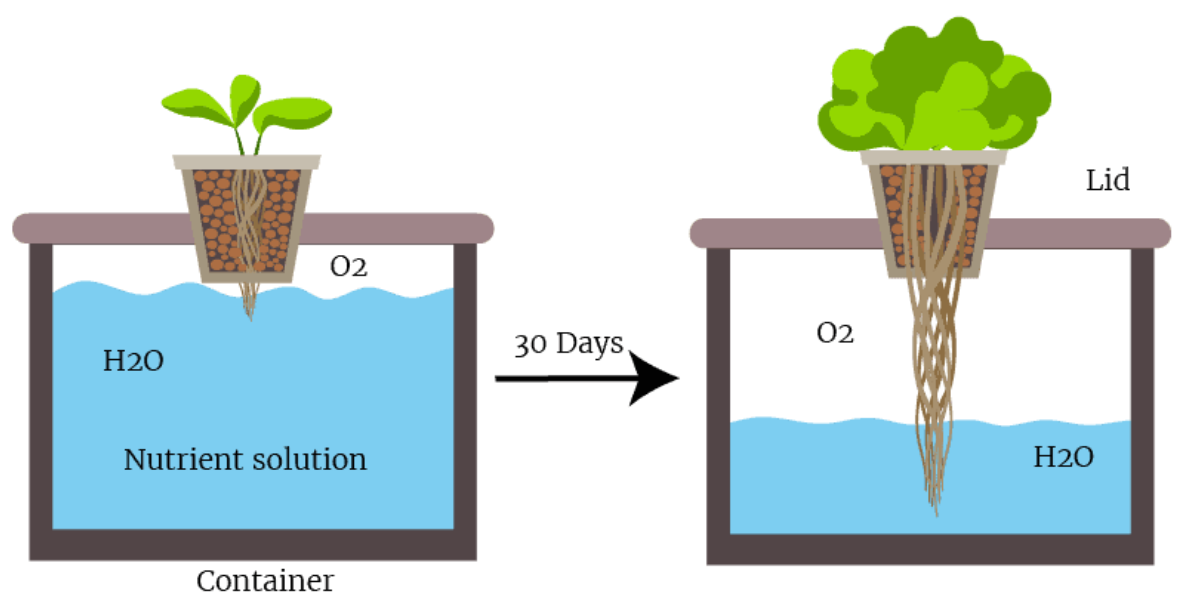

Figure 9. Diagram for a kartaky deep water culture hydroponic system.

\section{Requirements for Installing Deep Water Culture}

A deep water culture is easy to design on your own. What you will need:

A reservoir to contain water; 10-inch net pot; Air pump; Airline; Airstone; Some Rockwool/ expanding clay or any growing media of your choice; $\mathrm{pH}$ meter; $\mathrm{pH}$ kit.

\section{Advantages of Deep Water Culture}

Some of the advantages of deep water culture system are:

- Accelerated growth tanks to superior uptake of nutrients and oxygen from the nutrient solution. For example, you can grow lettuce and harvest in 30 days instead of 60 days in soil (Resh, 2012).

- Aerating the roots improves plants' absorption and increase cell growth rate within the plants (Bhattarai et al., 2006).

- Because the plants are submerged in deep water culture nutrients, there's no need for much fertilizer.

- Once you set it up, it requires little maintenance. There are no nozzles, feeder lines or water pumps to clog.

- Very little moving parts and assembly.

\section{Disadvantages of Deep Water Culture}

These are a few disadvantages of the DWC system given below:

- If the air pump gets broken, there is a very small window to replace it. If the air pump doesn't work for a long time, the plants will rapidly decline.

- If you are using a non-recirculating deep water culture system, it is difficult to maintain the temperature - the water tends to get too hot from the submersible pump running continuously. 
- The nutrient concentration, water level, and PH may fluctuate wildly in small systems.

- There is a risk of the plant roots drowning in low-oxygen nutrient solution if an electricity outage or a pump failure occurs.

- In small systems with a small scale, it is very easy to over or under calibrate.

- The biggest drawback of this kind of system is that it doesn't work well with large plants or with long-term plants.

\section{Choosing The Best Type of Garlic for Hydroponic?}

Globally there are different types of garlic available but the most common and best types are the following two.

\section{Hardneck Type Garlic}

Hardneck Garlics grow a scape through the centre of the garlic bulb. A Scape is a hard-long stem which grows a flower at the end. The flower at the end of the scape can be cut off and re-planted to grow more garlic. A bulb of hardneck garlic typically has between 4-12 cloves of garlic, depending on the species. These cloves are usually an even shape and size. The scape is edible as well. Hardneck Garlic grows better in colder climates, with the scapes blooming in early summer (Bachmann \& Hinman, 2008) (Figure 10A).

\section{Softneck Type Garlic}

The softneck variety of garlic, as the name suggests, doesn't grow a scape. This type of garlic is normally grown in warmer areas with more mild winters. Softneck bulbs have a higher yield of cloves, but they may not be consistent in shape and size. Their skin is usually softer and harder to peel than hardneck garlic but can be delicious to cool and consume whole (Platt, 2003) (Figure 10B).

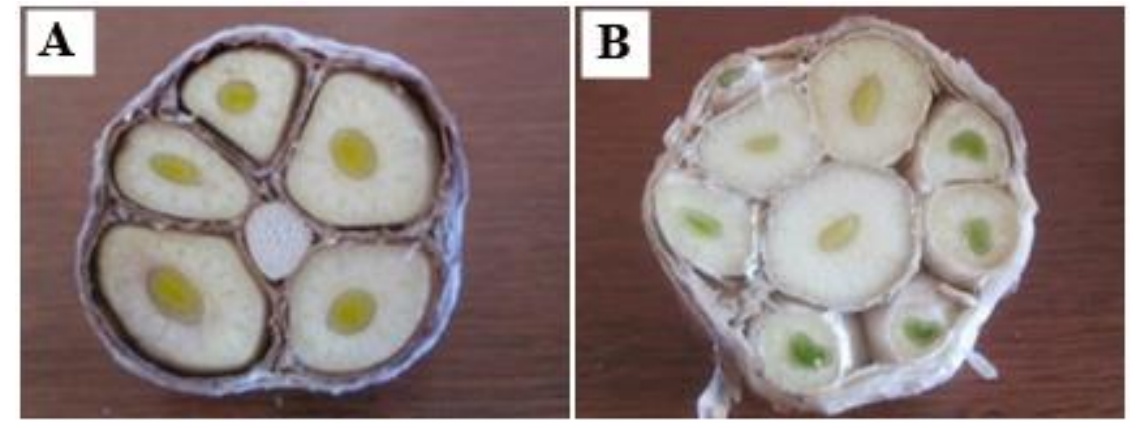

Figure 10. Hardneck type garlic (A) and softneck type garlic (B).

\section{Requirements for Growing Garlic under Hydroponic}

These are basic environmental factors which affect the garlic growth under hydroponic system. Schematic diagram for hydroponic garlic production can be presented in Figure 11.

\section{Light}

A plenty of light required for the optimum growth of garlic under hydroponic system. Minimum daily light of 6-8 hours and upto 10-12 hours is best for garlic 
growth. Garlic is a short-day plant so it does not need light for 24/7 (Baras, 2018). Artificial lights are necessary for better growth of garlic because garlic plant goes into dormancy during dark time (Lawande et al., 2009). These are the following types of lights which are commonly used in a hydroponic unit which includes; HID (high intensity discharge) lighting, LED (light-emitting diode) lighting, Fluorescent lighting, Metal halide (MH) lighting and High-pressure sodium (HPS) lighting (Gray, 2019).

\section{Temperature}

Temperature affects the garlic growth in two ways. High temperature accelerates the garlic growth which increases plants thirst for water. Higher temperature increases plant's consumption of water itself for cooling through evaporation (Nabhan, 2013). Garlic needs low temperature for its germination period which ranges from $30-85^{\circ} \mathrm{F}$ for short periods is fine (Shwerif, 2014). Different cultivars of garlic chooses cold weather to grow very best. Hardneck garlic is a bad choice for hydroponic systems as compared to softneck garlic which are tolerant to warm temperatures.

Air

Air movement have a dramatic influence on the plant's consumption of water especially when the temperature is high. Air removes the water easily from plants as the clothes dry easily under sun and same applies in the case of garlic hydroponic production (Deppe, 2010).

\section{Carbon dioxide}

Carbon dioxide is necessary for a plant to stay alive; it is need in photosynthesis, growth, yield and development of plants (Smith et al., 2018). Garlic growing dynamically in a greenhouse can diminish the carbon dioxide of greenhouse. So, for growing garlic at large scale in greenhouse or at hydroponic farm it is necessary to supply carbon dioxide from external sources (Morris, 2001).

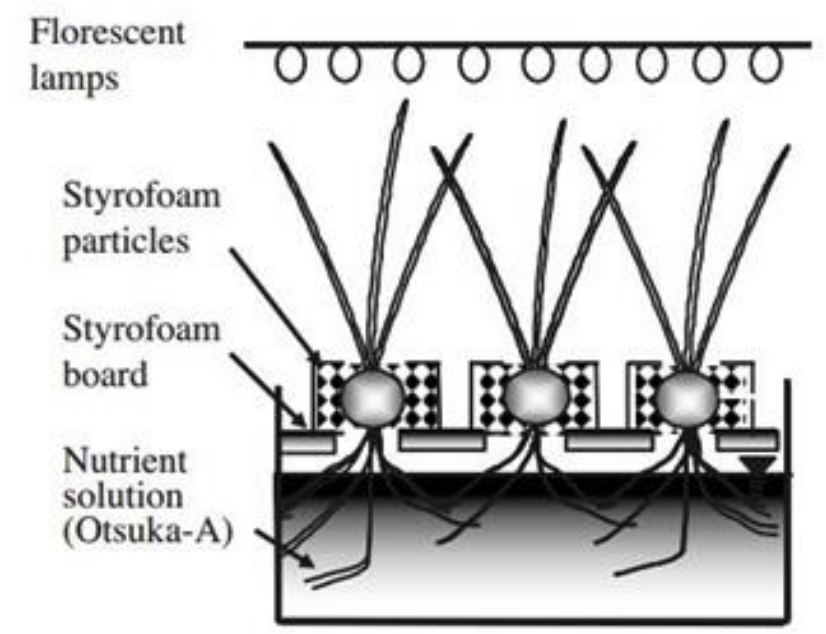

Figure 11. Schematic diagram for hydroponic garlic production.

\section{Hydroponics vs Conventional System for Garlic Production}

The comparison of conventional with hydroponic systems for garlic production can be presented in Table 5 . 
Table 5. Comparison of conventional and hydroponics system for garlic production

\begin{tabular}{|c|c|c|}
\hline & Conventional & Hydroponics \\
\hline $\begin{array}{l}\text { Production } \\
\text { Duration }\end{array}$ & Seasonal & Year round \\
\hline $\begin{array}{l}\text { Land use } \\
\text { efficiency }\end{array}$ & $\begin{array}{l}\text { Less due to Variation in soil } \\
\text { fertility; Competition with } \\
\text { weeds; Less water availability }\end{array}$ & $\begin{array}{l}\text { As no soil is used so no such } \\
\text { problems thus there is high } \\
\text { plant density (more plants per } \\
\text { square meter) }\end{array}$ \\
\hline $\begin{array}{l}\text { Water use } \\
\text { efficiency }\end{array}$ & $\begin{array}{l}\text { Less due to Shortage of water; } \\
\text { High evaporation losses; Less } \\
\text { irrigation efficiency }\end{array}$ & $\begin{array}{l}\text { Require } 1 / 30 \text { the amount of } \\
\text { water that is required for } \\
\text { same area with conventional } \\
\text { method. }\end{array}$ \\
\hline $\begin{array}{l}\text { Soil } \\
\text { degradation }\end{array}$ & $\begin{array}{l}\text { High due to poor irrigation } \\
\text { efficiency, high dosage of } \\
\text { fertilizer and pesticides resulting } \\
\text { in problems such as water } \\
\text { logging and salinity }\end{array}$ & $\begin{array}{l}\text { No soil is used in this system } \\
\text { thus no damage is done to it. }\end{array}$ \\
\hline Resource utility & $\begin{array}{l}\text { More land, labour and capital is } \\
\text { required }\end{array}$ & $\begin{array}{l}\text { Efficient and profitable } \\
\text { utilization of natural and } \\
\text { artificial resources }\end{array}$ \\
\hline $\begin{array}{l}\text { Resource } \\
\text { conservation }\end{array}$ & $\begin{array}{l}\text { All-natural resources such as } \\
\text { water fertilizer are used in a } \\
\text { non-cyclic way. (They are used } \\
\text { only once and not again } \\
\text { resulting in wastage of these } \\
\text { valuable resources }\end{array}$ & $\begin{array}{l}\text { All-natural resources such as } \\
\text { water fertilizer are used in } \\
\text { cyclic that is cyclic that is } \\
\text { they are used again and again }\end{array}$ \\
\hline $\begin{array}{l}\text { Competition } \\
\text { with weeds }\end{array}$ & High competition & Little or no risk of weeds \\
\hline $\begin{array}{l}\text { Intensity of } \\
\text { pest/disease } \\
\text { attack }\end{array}$ & High risk & $\begin{array}{l}\text { Less chances as there are } \\
\text { many barrier }\end{array}$ \\
\hline $\begin{array}{l}\text { Effect of } \\
\text { location }\end{array}$ & $\begin{array}{l}\text { Location affects production due } \\
\text { to different climatic condition at } \\
\text { different location }\end{array}$ & $\begin{array}{l}\text { Environment is controlled } \\
\text { artificially so location does } \\
\text { not affect crop production }\end{array}$ \\
\hline $\begin{array}{l}\text { Benefit cost } \\
\text { ratio }\end{array}$ & Less & High \\
\hline Quality & $\begin{array}{l}\text { Low because field } \\
\begin{array}{l}\text { grower } \\
\text { cannot control }\end{array} \\
\text { parameters }\end{array}$ & $\begin{array}{l}\text { Grower can influence quality } \\
\text { parameter by adjusting } \mathrm{pH} \text {, } \\
\text { EC etc. }\end{array}$ \\
\hline Market value & $\begin{array}{l}\text { Less due to poor and variable } \\
\text { quality }\end{array}$ & $\begin{array}{l}\text { Market value is high due to } \\
\text { uniformity in size shape } \\
\text { colour and weight }\end{array}$ \\
\hline Shelf life & Short & Long \\
\hline $\begin{array}{l}\text { Consistency in } \\
\text { production }\end{array}$ & $\begin{array}{l}\text { Very little or no consistency } \\
\text { because production is dependent } \\
\text { upon climatic conditions }\end{array}$ & $\begin{array}{l}\text { More consistent production } \\
\text { because production because } \\
\text { production is not dependent } \\
\text { upon climatic condition }\end{array}$ \\
\hline
\end{tabular}




\section{CONCLUSION}

It is concluded from the above facts and figures that due to increase in population, climate change, soil borne diseases and low yield of garlic in soil medium this is today demand that if we want to achieve more yield and want to earn handsome profits in garlic production than we should shift our garlic production systems to hydroponic system from soil. Hydroponic system has the ability to give more yield, nutrition to garlic which are free from pest and diseases and also have much food security than the conventional production of garlic

\section{REFERENCES}

Bachmann, J., \& Hinman, T. (2008). Garlic: Organic production. National Center for Appropriate Technology (NCAT). A Publication of ATTRA, 1-28 p. http://michaeljbowe.com/TSG/SG/SF_00202.pdf.

Baras, T. (2018). DIY hydroponic gardens: How to design and build an inexpensive system for growing plants in water. United States: Cool Springs Press.

Bhattarai, S. P., Pendergast, L., \& Midmore, D. J. (2006). Root aeration improves yield and water use efficiency of tomato in heavy clay and saline soils. Scientia Horticulturae, 108(3), 278-288. https://doi.org/10.1016/j.scienta.2006.02.011.

Bindhya, B. N., Murugan, R. J., \& Thomas, U. C. (2020). Hydroponics: A potential agrarian future. In Advances in Agronomy, vol. 13. p.136. India: AkiNik Publications.

Borlinghaus, J., Albrecht, F., Gruhlke, M. C., Nwachukwu, I. D., \& Slusarenko, A. J. (2014). Allicin: chemistry and biological properties. Molecules, 19(8), 1259112618. https://doi.org/10.3390/molecules190812591.

Casado, F. J., López, A., Rejano, L., Sánchez, A. H., \& Montaño, A. (2004). Nutritional composition of commercial pickled garlic. European Food Research and Technology, 219(4), 355-359. https://doi.org/10.1007/s00217-004-1003-5.

Conn, S. J., Hocking, B., Dayod, M., Xu, B., Athman, A., Henderson, S., Aukett, L., Conn, V., Shearer, M. K., Fuentes, S., Tyerman, S. D., \& Gilliham, M. (2013). Protocol: optimising hydroponic growth systems for nutritional and physiological analysis of Arabidopsis thaliana and other plants. Plant Methods, 9(1), 1-11. https://doi.org/10.1186/1746-4811-9-4.

Deppe, C. (2010). The resilient gardener: Food production and self-reliance in uncertain times. United States: Chelsea Green Publishing.

Folorunso, E. A., Roy, K., Gebauer, R., Bohatá, A., \& Mraz, J. (2021). Integrated pest and disease management in aquaponics: A metadata-based review. Reviews in Aquaculture, 13(2), 971-995. https://doi.org/10.1111/raq.12508.

Godfray, H. C. J., Beddington, J. R., Crute, I. R., Haddad, L., Lawrence, D., Muir, J. F., Pretty, J., Robinson, S., Thomas, S. M., \& Toulmin, C. (2010). Food security: the challenge of feeding 9 billion people. Science, 327(5967), 812-818. https://doi.org/10.1126/science.1185383.

Government of Punjab. (2019). Garlic production plan 2019-20. Directorate of Agricultural Information. Government of Punjab, Pakistan.

Gray, L. (2019). Lighting and economic considerations for a hydroponic S-based greenhouse at tri cycle farms. Undergraduate Theses. Department: Biological and Agricultural Engineering, University of Arkansas, Fayetteville, United States. https://scholarworks.uark.edu/baeguht/58/. 
Halleck, L. F. (2018). Gardening under lights: The complete guide for indoor growers. Portland, United States: Timber Press Inc.

Lawande, K. E., Khar, A., Mahajan, V., Srinivas, P. S., Sankar, V., \& Singh, R. P. (2009). Onion and garlic research in India. Journal of Horticultural Sciences, 4(2), 91-119. https://jhs.iihr.res.in/index.php/jhs/article/view/527.

Lissiman, E., Bhasale, A. L., \& Cohen, M. (2014). Garlic for the common cold (Review). Cochrane Database of Systematic Reviews, 11, 1-18. https://doi.org/10.1002/14651858.CD006206.pub4.

Morihara, N., Nishihama, T., Ushijima, M., Ide, N., Takeda, H., \& Hayama, M. (2007). Garlic as an anti-fatigue agent. Molecular Nutrition \& Food Research, 51(11), 1329-1334. https://doi.org/10.1002/mnfr.200700062.

Morris, J. L. (2001). Composition and flavonoid levels in onions (Allium cepa) grown in hydroponics in greenhouses and growth chambers. Theses. Texas Tech University, Lubbock, United States. https://tu-ir.tdl.org/handle/2346/19319.

Müller, N. T., Gerson, R. D. L., Nascimento, G. C., \& Daniels, J. (2000). 334 Meristem isolation of garlic (Allium sativum L.) cultivars Sao Marcos and Sao Valentim. HortScience, 35(3), 449D-449. https://doi.org/10.21273/HORTSCI.35.3.449D.

Nabhan, G. P. (2013). Growing food in a hotter, drier land: lessons from desert farmers on adapting to climate uncertainty. White River Junction, United States: Chelsea Green Publishing.

Naznin, M, T., Kitaya, Y., Shibuya, T., \& Hirai, H. (2009). Development of hydroponic culture system for producing garlic and determination of ajoene concentration. Eco-Engineering, 21(4), 147-152. https://doi.org/10.11450/seitaikogaku.21.147.

Paek, K. Y., Chakrabarty, D., \& Hahn, E. J. (2005). Application of bioreactor systems for large scale production of horticultural and medicinal plants. In Liquid culture systems for in vitro plant propagation (pp. 95-116). Springer, Dordrecht. https://doi.org/10.1007/1-4020-3200-5_6.

Pardossi, A., Carmassi, G., Diara, C., Incrocci, L., Maggini, R., \& Massa, D. (2011). Fertigation and substrate management in closed soilless culture. EUPHOROS Report, https://citeseerx.ist.psu.edu/viewdoc/download?doi=10.1.1.501.28\&rep=rep1\&t ype $=$ pdf.

Platt, E. S. (2003). Garlic, onion, \& other alliums. Mechanicsburg, United States: Stackpole Books.

Prayoga, I., \& Putra, R. A. (2020). Hydroponic technology in agriculture industry. IOP Conference Series: Materials Science and Engineering, 879, 012130.

Resh, H. M. (2012). Hydroponic food production: a definitive guidebook for the advanced home gardener and the commercial hydroponic grower. Florida, United States: CRC Press.

Rivlin, R. S. (2001). Historical perspective on the use of garlic. The Journal of Nutrition, 131(3), 951S-954S. https://doi.org/10.1093/jn/131.3.951S.

Saleem, A. (2018). EIA for the proposed agricultural development at N. Maafunafaru. Project Synopsis. http://saruna.mnu.edu.mv/jspui/handle/123456789/3027.

Shwerif, N. (2014). Effects of temperature regimes under low light conditions on growth rate and phytochemical composition of lettuce and carrot plants. Theses. Newcastle University, United Kingdom. https://theses.ncl.ac.uk/jspui/handle/10443/2390. 
Singh, D., \& Sharma, R. R. (2018). Postharvest diseases of fruits and vegetables and their management. In Postharvest disinfection of fruits and vegetables (pp. 152). Academic Press. https://doi.org/10.1016/B978-0-12-812698-1.00001-7.

Smith, M. R., Rao, I. M., \& Merchant, A. (2018). Source-sink relationships in crop plants and their influence on yield development and nutritional quality. Frontiers in Plant Science, 9, 1889. https://doi.org/10.3389/fpls.2018.01889.

Suleria, H. A. R., Butt, M. S., Khalid, N., Sultan, S., Raza, A., Aleem, M., \& Abbas, M. (2015). Garlic (Allium sativum): diet based therapy of $21^{\text {st }}$ century-a review. Asian Pacific Journal of Tropical Disease, 5(4), 271-278. https://doi.org/10.1016/S2222-1808(14)60782-9.

Tank, J. L., Reisinger, A. J., \& Rosi, E. J. (2017). Nutrient limitation and uptake. In Methods in Stream Ecology (pp. 147-171). Academic Press. https://doi.org/10.1016/B978-0-12-813047-6.00009-7.

Vinci, G., \& Rapa, M. (2019). Hydroponic cultivation: life cycle assessment of substrate choice. British Food Journal, 121(8), 1801-1812. https://doi.org/10.1108/BFJ-02-2019-0112.

Zarezadeh, M., Baluchnejadmojarad, T., Kiasalari, Z., Afshin-Majd, S., \& Roghani, M. (2017). Garlic active constituent s-allyl cysteine protects against lipopolysaccharide-induced cognitive deficits in the rat: Possible involved mechanisms. European Journal of Pharmacology, 795, 13-21. https://doi.org/10.1016/j.ejphar.2016.11.051. 